\title{
0 том, что фактически должно лежать в основе установления границ объектов культурного наследия в виде Достопримечательных мест. Часть 2
}

\author{
Э.А.Шевченко, НИУ МГСУ, Москва \\ А.В.Лукашев, НКО «Фонд «ИПУРГ»
}

Вторая часть статьи ${ }^{1}$ посвящена рассмотрению четырёх разновидностей ДМ:

- «памятные места, культурные и природные ландшафты, связанные с историей формирования народов и иных этнических общностей на территории Российской Федерации, историческими (в том числе военными) событиями, жизнью выдающихся исторических личностей;

- объекты археологического наследия;

- места совершения религиозных обрядов;

- места захоронений жертв массовых репрессий;

- религиозно-исторические места».

Разновидность «места захоронений жертв массовых репрессий» требует отдельного, тщательного анализа и здесь не рассматривается. Этой теме будет посвящена отдельная статья.

Разновидность ДМ - «памятные места, культурные и природные ландшафты, связанные с историей формирования народов и иных этнических общностей на территории Российской Федерации, историческими (в том числе военными) событиями, жизнью выдающихся исторических личностей», фактически состоит из трёх самостоятельных ОКН ДМ: ДМ - памятные места, культурные и природные ландшафты, связанные с историей формирования народов и иных этнических общностей на территории Российской Федерации; ДМ - памятные места связанные с историческими (в том числе военными) событиями; ДМ - памятные места связанные с жизнью выдающихся исторических личностей.

Сложность «конструкции» понятия «ДМ - “памятные места, культурные и природные ландшафты, связанные с историей формирования народов и иных этнических общностей на территории Российской Федерации"» вызвана межотраслевым характером данного ОКН и неопределённостью введённых в понятие терминов, таких как «место» и «культурный ландшафт» при конкретно установленной цели фиксации ДМ как территорий Российской Федерации, на которых происходило «формирование народов и иных этнических общностей».

Изучением истории происхождения народов и этносов занимаются демографы, этнографы и этнологи, философы, социологи и др., и, следовательно, при обосновании данной разновидности ДМ именно специалисты этих профессий должны дать обоснование границ территории ДМ. Но закон
№ 73-Ф3, определив ДМ как объекты недвижимого имущества, отнёс их «(включая объекты археологического наследия) и иные объекты с исторически связанными с ними территориями, произведениями живописи, скульптуры, декоративноприкладного искусства, объектами науки и техники и иными предметами материальной культуры, возникшие в результате исторических событий, представляющие собой ценность с точки зрения истории, археологии, архитектуры, градостроительства, искусства, науки и техники, эстетики, этнологии или антропологии, социальной культуры и являющиеся свидетельством эпох и цивилизаций, подлинными источниками информации о зарождении и развитии культуры», к объектам культурного наследия и, следовательно, несмотря на то, что применительно к данной разновидности ДМ, этот объект с исторически связанными с ним территориями, должен представлять главную ценность с точки зрения этнологии или антропологии, следует доказывать ценность как «свидетельство эпох и цивилизаций, подлинного источника информации о зарождении и развитии культуры» народов России.

В поисках этих территорий-мест следует обратиться к трактовкам понятий «этнос ${ }^{2}$ и народ», но эта тема не является предметом данной статьи. Применительно к данной разновидности ДМ следует определиться с возможным предметом охраны как неотъемлемым доказательством существования ДМ как недвижимого объекта. Но ответ на вопрос «что представляет собой предмет охраны этой разновидности ДМ?» лежит в плоскости понятий «этнос» и «народ». Древние греки употребляли слово «этнос», обозначая другие народы, не являющиеся греками. Характерными признаками этноса в данном понимании являются общность территории проживания, наличие общего исторического прошлого, единого языка, культуры, особенностей психики. Именно перечисленные характеристики могут способствовать фиксации территорий ДМ, где этнос сформировался как таковой. Но чем отличается этнос от народа и как это различие будет способствовать фиксации этих ДМ?

Возникает и другой правомерный вопрос относительно того, пришли ли к единому мнению специалисты в определении этих понятий, если «этнос» в переводе с греческого означает «народ»³? В 2013 году в статье «Народ. Этнос. На-

\footnotetext{
${ }^{1}$ Первая часть статьи «0 том, что фактически должно лежать в основе установления границ объектов культурного наследия в виде Достопримечательных мест» опубликована в № 1 журнала «Асаdemia. Архитектура и строительство» за 2019 год.

${ }^{2}$ В научный оборот понятие «этнос» было введено в 1923 году русским учёным-эмигрантом С. М. Широкогоровым.

3 Этнос (греч. $\check{\theta} \theta$ vo - народ) - в некоторых теориях этничности, исторически сложившаяся устойчивая совокупность людей, объединённых общими объективными либо субъективными признаками, в которые различные авторы включают происхождение, единый язык, культуру, хозяйство, территорию проживания, самосознание, внешний вид...
} 
ция» ${ }^{4}$ её автор Ю.И. Семёнов писал «Слова “народ”, “этнос” и "нация" зачастую употребляются как синонимы. Согласиться с этим нельзя». Ю.И. Семенов считал, что, только разобравшись с понятием «общество», можно получить ответ на вопрос о различии понятий «народ» и «этнос». Дискуссия продолжается и сегодня. По этой причине для решения нашей задачи мы будем считать понятия «народ» и «этнос» синонимами, так как задача фиксации ДМ заключается в установлении «места» или «культурных и природных ландшафтов», на которых общность (или этнос-народ) сформировалась. В этом плане вся территория Российской Федерации может быть признана достопримечательным местом, так как на протяжении веков здесь происходили процессы формирования народов и этносов, в том числе путём ассимиляции различных этносов, адаптации культур и, следовательно, формирования новых.

Специалисты фиксировали и много иных процессов становления национальной самоидентификации народов и этносов Российской Федерации. Но если серьёзно, то что взять за основу критерия установления границ территорий ДМ, на которых они формировались? Можно ли отнести к территориям достопримечательных мест чудом сохранившиеся в Ярославской, Костромской, Тверской областях и много ещё где осколки некогда огромного финно-угорского народа, некогда заселявшего огромные пространства центральной России? Можно ли локализовать место (места) традиционного проживания волжских болгар? Наука сегодня лишь по касательной приближается к вопросам возникновения, бытования и переселения народов - на этом пути нас ждёт ещё немало открытий и сюрпризов. Поэтому, устанавливая такие достопримечательные места, мы рискуем допустить немало ошибок и неточностей, которые могут иметь самые непредсказуемые последствия (рис. 1).

Можно обратиться к идее английского историка права и юриста Генри Джеймса Самнера Мейна (1822-1888), доказывавшего существование двух видов обществ, в основе одного из которых лежит родство, а в основе второго - земля или территория. Но ведь община, сформированная на личностно-родовых отношениях, обитала на каких-то территориях. В чем отличие и каков принцип установления пределов-границ территорий, на которых происходило формирование этноса, народа? Собственно предмет нашей задачи - установление именно территории, на которой общество формировалось и изменялось. Как считал американский этнолог Льюис Генри Морган (1818-1881), развивший идею Генри Джеймса Самнера Мейна, два «типа» общества совершенно различны по принципам основания. Семёнов пишет о том, что указанные два типа общества различались «... не наличием или отсутствием у них территории, а принципами, лежавшими в основе их организации, что предопределяло разное их отношение к территории». Однако обращает на себя внимание указание на то, что «общество» уже сложилось, и тогда задача фиксации ДМ может показаться простой - определиться с территорией (местом), в пределах которой общество (в составе народов или этносов) формировалось, обживая территорию, то есть осуществляя на ней хозяйственную деятельность. В этом случае необходимо установить размер территории, способной прокормить всех членов общины.

Вряд ли можно принять столь простой способ установления границ территории данного ДМ, потому что нельзя идентифицировать понятие «общество» - «народ» - «этнос», так как до настоящего времени специалисты, как уже было сказано, не пришли кединому мнению в этом вопросе. В таком случае, что мы собираемся фиксировать и как в этом случае принимать заключение эксперта, подтверждающего или отрицающего достоверность обоснований «места» и границ

${ }^{4}$ Журнал: «Философия и общество». Выпуск № 1 (69)/2013. Полное или частичное копирование материалов сайта www.socionauki.ru разрешено только при обязательном указании автора и прямой гиперссылки\% https://www.socionauki.ru/journal/articles/153057/

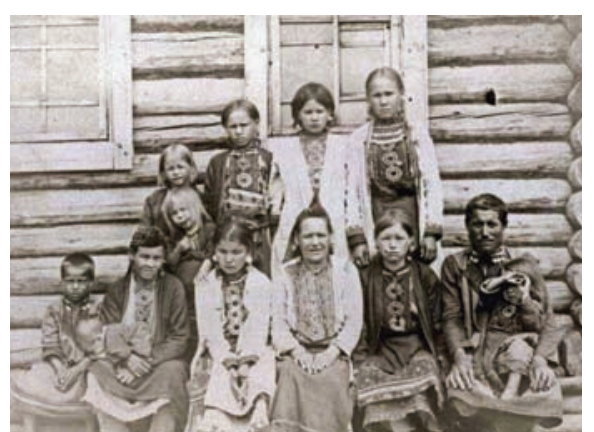

a)

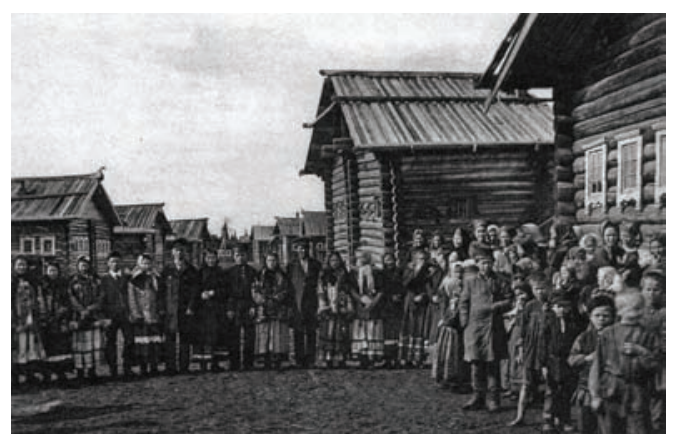

б)

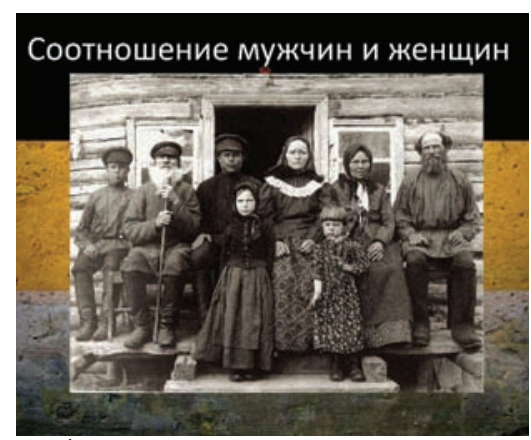

B)

Puс. 1. Народы России: а) марийцы Красноуфимска (источник: https://i.pinimg.com/originals/b0/ae/b2/b0aeb23961f9a0 d466bac7107e807563.jpg); б) архангельские поморы (источник: https://img-fotki.yandex.ru/get/9227/97833783.3bc/0_ af592_494e17c6_XXXL.jpg); в) русские Тульской губернии (источник: https://cf.ppt-online.org/files/slide/c/CRPGXezJ1T2f4My homjABnOE3cvl8q0ZubrFHi/slide-8.jpg) 
этого ДМ? Сегодня, согласно последней переписи населения, в России проживает более 190 народов и этнических групп. Мы не будем разбираться, в чем различие этих терминов, это тема специалистов другой профессии, для нас необходимо выяснить для каких из этих 190 народов и этносов следует определить места их формирования в целях фиксации территории ДМ как «памятного места, культурных и природных ландшафтов, связанных с историей формирования народов и иных этнических общностей на территории Российской Федерации», установления границы территории этого ДМ, предмета охраны и обоснования требований к регламентам для этого объекта культурного наследия (это требование закона №73-Ф3 статья 33, п. 10, статья 56.4). Но, возможно, законодатель, вводя эту разновидность ДМ, имел в виду территории, на которых в разный период времени жили исчезнувшие к настоящему времени народы, такие как хазары, кривичи или меря, сибирские бухарцы, скифы? Изначально необходимо ответить на вопрос о цели фиксации столь специфического ДМ и установления границ этого объекта недвижимости 5 . Фиксация ДМ возможна при условии принятия доминантного критерия, позволяющего зафиксировать территорию ОКН в чётких границах, потому что без фиксированной границы нет объекта недвижимости, а мы именно его должны сформировать, именно он должен быть внесён в соответствующий государственный реестр (реестр недвижимости, земельный кадастр, реестр объектов культурного наследия). Таким образом, возникает тема «места» или земельного участка (что соответствует трактовке понятия объект недвижимости в Земельном кодексе).

Очень интересную трактовку понятию «место» даёт В.Л. Каганский: «Место - неопределённая категория... Всякое место - равно предмет и позиция видения» [1]. Другого определения применительно к предмету градостроительного объекта нет. Следовательно, необходимо проанализировать практику применения данного понятия и предложить уточнённую формулировку в закон. Здесь очевидно только то, что некое Место (вероятнее всего, это территория или пространство) является «памятным», то есть хранящим информацию о событиях, явлениях ценных для истории и культуры народов. Следовательно, определяющим здесь является указание на некую территорию, на которой произошли какие-то события. В данном случае это территории, на которых формировались народы и иные этнические общности, представляющие сегодня население современной России.

Следующим неопределённым и ненормативным компонентом введённого в закон понятия является «культурный ландшафт». Использование в федеральном законодательном

${ }^{5}$ В соответствии с №73-Ф3 ст. 3 «к объектам культурного наследия (памятникам истории и культуры) народов Российской Федерации (далее - объекты культурного наследия) в целях настоящего Федерального закона относятся объекты недвижимого имущества ...», достопримечательные места являются третьим видом объектов культурного наследия наряду с «памятниками» и «ансамблями». документе терминологии, которая имеет толкование, а не нормативное раскрытие понятия, типично для федерального закона №73-Ф3.

В книге «Культурный ландшафт как объект наследия» Ю.А. Веденин и М.Е. Кулешова предложили такую формулировку понятия: «Культурный ландшафт - природно-культурный территориальный комплекс, сформировавшийся в результате эволюционного взаимодействия природы и человека, его социокультурной и хозяйственной деятельности и состоящий из характерных сочетаний природных и культурных компонентов, находящихся в устойчивой взаимосвязи и взаимообусловленности», но в закон эта трактовка так и не попала.

В целях фиксации ДМ «памятные места, культурные и природные ландшафты...» понятие «культурный ландшафт» мало применимо, так как в период формирования народов и этносов ландшафт был в значительной степени первозданным, природным и окультурен он был значительно позже, в процессе начальной стадии урбанизации территорий, то есть с момента начала планомерного строительства поселений, систем расселения, фортификационно-жилых образований - засечных черт. Но условно начальной стадией урбанизации следует считать XVI век, начало формирования государственности и устойчивого и планомерного формирования системы расселения молодого государства. И если к этому периоду основная масса этносов и народов уже сформировались, то изучать следует период до XVI века. В этой ситуации основой выявления этой разновидности ДМ может быть этногенез ${ }^{6}$ и этногеография ${ }^{7}$. Именно на основании данных этногенеза и этногеографии появляется возможность ответить на вопросы о местах-территориях начальных этапов возникновения народов, динамики их формирования, особенностях расселения в прошлом и настоящем в целях определения этнических границ. Ведь только ответ на эти вопросы позволит с большей степенью достоверности установить границу ОКН ДМ данной разновидности, фиксирующую территорию зарождения какой-либо этнической общности или народа как места общей истории развития народа или этноса и формирования общей культуры. При определении границ этой разновидности ДМ следует пользоваться материалами и данными этнической картографии и этнической демографии. Однако достижение поставленной законом цели - фиксации территорий зарождения народов и этносов - может иметь непредсказуемые последствия для целостности государства и формирования единого гражданского общества.

В предисловии к монографии «Культурный ландшафт...» директор Центра Всемирного наследия ЮНЕСКО Франческо Бандарин сказал, что «культурный ландшафт - один из таких компонентов и, кстати, основополагающая категория наследия, так как он олицетворяет множество культурных и природных ценностей в их единстве и взаимодействии. Культурные ландшафты представляют национальный дух народов и их традиционный стиль жизни <...> понятие "культурный ландшафт" не ограничивается материальными субстанциями, 
а включает в себя семантический слой, создаваемый этносами и фиксируемый в фольклоре и топонимике». Да, всё именно так, и автор этого высказывания сам указывает на то, что «культурный ландшафт» создаётся этносами, следовательно, они уже сформировались и, возможно, на территории, на которой и продолжают существовать, а если нет, от остаётся выяснить, где и когда. Ответ на этот вопрос и укажет местотерриторию формирования, являющуюся ДМ «с историей формирования народов и иных этнических общностей».

Если это так, то для установления территорий ДМ - «мест формирования народов и этносов», культурный ландшафт как категория, определяющая это место, использоваться не может. В настоящее время подобных ДМ на территории Российской Федерации не установлено, но есть, например, природный парк «Вепсский лес», созданный на территории традиционного проживания вепсов, как особо охраняемая природная территория регионального значения в Ленинградской области. Парк был создан в 1999-2003 годах, площадь территории этого парка составляет 189,1 тыс. га. Так как парк, как следует из пояснительной записки, был создан на территории традиционного проживания вепсов, то одна из функций заключалась в стимулировании возрождения вепсского языка и культуры. Если доказано, что именно на этой территории вепсы проживали постоянно, а не мигрировали сюда из каких-то иных земель, то очевиден вывод - это место фактического формирования этого народа, именно здесь, в некоем природном ареале

\footnotetext{
${ }^{6}$ Этногенез - происхождение народов, включает как начальные этапы возникновения народа, так и дальнейшее формирование его этнографических, лингвистических и антропологических особенностей (Советский энциклопедический словарь / гл. ред. А.М.Прохоров. 3-е изд. - М. : Сов. Энциклопедия, 1985. - 1600 с., ил.).

${ }^{7}$ Этногеграфия - раздел этнографии, изучающий особенности расселения в прошлом и настоящем... для определения этнических границ, динамики... народов (Советский энциклопедический словарь / гл. ред. А.М.Прохоров. 3-е изд. - М. : Сов. Энциклопедия, 1985. - 1600 с., ил.).
}

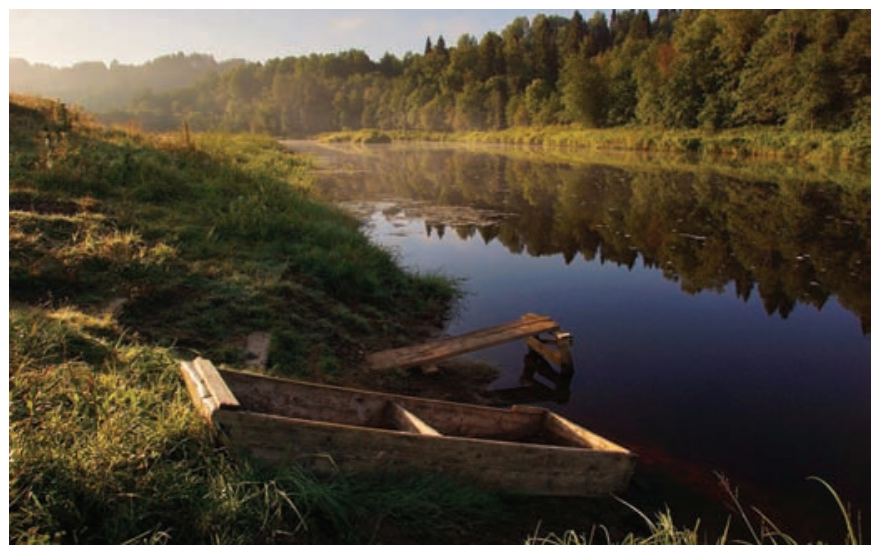

a)

Puc. 2. Природный парк «Вепсский лес»: a) источник - http://www.vepsles.spb.ru/images/5bMA9.jpg; б) источник - https:// pp.userapi.com/c841228/v841228237/34ccb/TOAVUf2Rmno.jpg вепсы сформировались как народ. В этом случае можно утверждать, что природный парк «Вепсский лес» является ДМ - «памятные места, связанные с историей формирования народов и иных этнических общностей на территории Российской Федерации» (рис. 2).

Возможно, что народы, проживающие сегодня на этих территориях, являются потомками и киммерийцев, и скифов, и сарматов или иных народов, населявших некогда территорию страны. Есть на этих территориях не только ландшафтно-природное диво, но и исторические поселения, и уже одно это делает эту территорию уникальным ОКН вида ДМ - «памятные места, культурные и природные ландшафты, связанные с историей формирования народов и иных этнических общностей на территории Российской Федерации». Но полноценный ответ для установления достоверных границ такого ДМ может быть получен на основании сведений этногенеза и этногеографии.

И ещё одна проблема: какие обременения (ограничения) на осуществление хозяйственной и градостроительной деятельности, действующие на протяжении столетий на фиксируемом участке территории, могут быть предложены, кроме требований по сохранению существующего ландшафта? Но ведь на этой территории может к настоящему времени находиться поселение и что с ним делать? Предметом охраны этого ДМ оно быть не может, это очевидно. Также очевидно и то, что без предмета охраны не может быть и ДМ. Возникает вопрос: а с какой стати вообще следует устанавливать ДМ такой разновидности, тем более что практически вся территория России была долгие столетия местом формирования народов и этносов, населяющих современную Россию? И еще, какой ландшафт следует сохранять: тот который существовал во времена формирования этноса или народа? На вопрос о том, каким он был, могут ответить палеоландшафтоведы или палеогеографы. Но ландшафта того периода уже нет, и следовательно, доста-

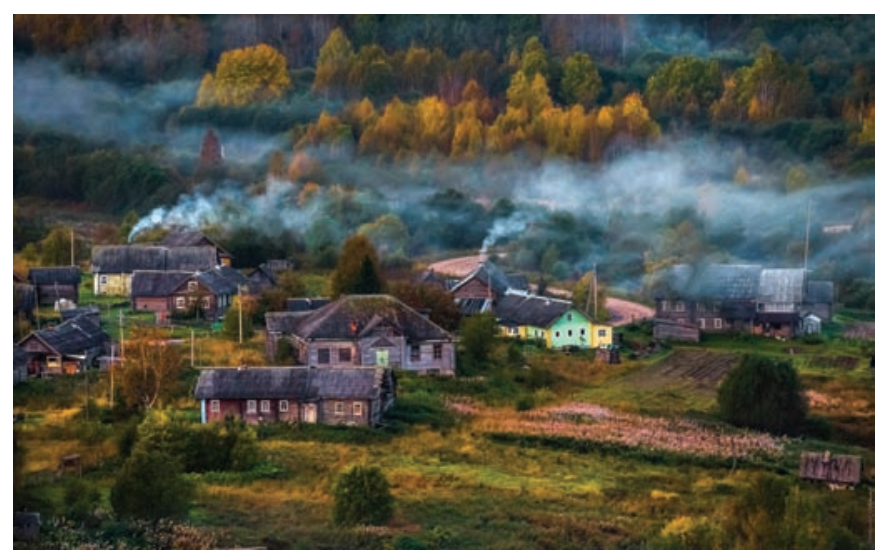

B) 
точно установить условный знак в условно принятой точке территории. И ВСЁ!!! Зачем устанавливать границы некоей территории и делить территорию Российской Федерации на местечковые уделы?

Мы все потомки некогда проживавших на территории России народов и этносов, в каждом из нас течёт кровь и татар, и русичей, и чувашей, и монголов и финно-угров, и

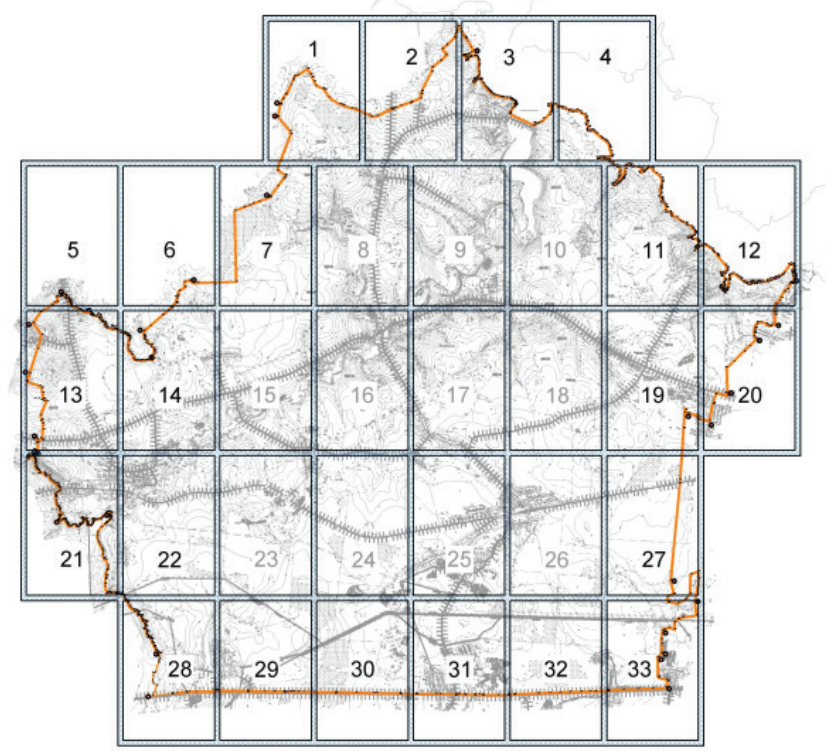

a)

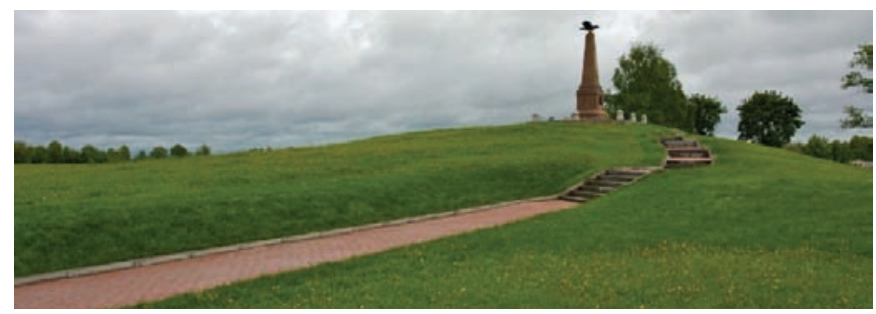

б)

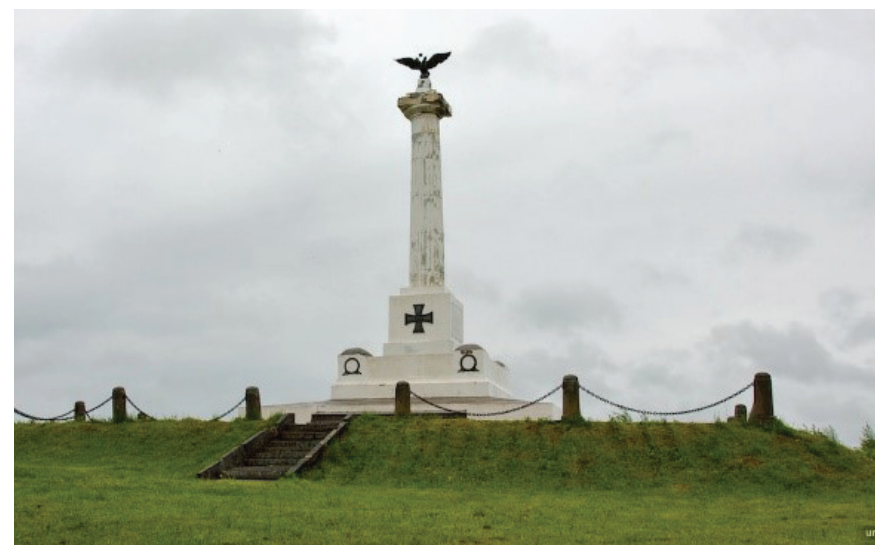

B)

Рис. 3. Схема территории ДМ «Бородинское поле и памятники на нём»: а) схема границ территории (источник: https:// cdnimg.rg.ru/pril/62/67/31/borodino.pdf); б, в) памятники славы (фото Лукашева) скандинавов и еще много кого. Ведь не случайно великий А. Блок в стихотворении «Скифы», имея ввиду все народы Российской Империи, возводя нас до статуса уникального и единственного в своем своеобразии народа мира, писал:

Да, скифы-мы! Да, азиаты - мы,

С раскосыми и жадными очами!

Для вас - века, для нас - единый час.

Мы, как послушные холопы,

Держали щит меж двух враждебных рас

Монголов и Европы!

В этой же разновидности ДМ приведена и такая: «памятные места, связанные с историческими (в том числе военными) событиями».

Название этой разновидности ДМ позволяет предположить, что установление границ территории в части мест военных событий является простой задачей, так как места, где происходили эти события, известны, и достаточно проанализировать военные карты и другие источники, чтобы обосновать черту-границу, отделяющую территорию ОКН ДМ от окружающего объект ландшафта. При установлении границ ДМ, связанного с военными событиями, изначально следует решить вопрос, какова идея ДМ, заключается она исключительно в фиксации поля боевых действий или в желании охватить границами максимально возможную площадь территории, примыкающей к месту непосредственных боевых действий. Стремление включить в границы ДМ максимально возможную площадь оправдана тем, что окружающие место непосредственных военных действий, ландшафты рассматриваются как негласные свидетели тех далёких событий.

Примером такого подхода является объект культурного наследия федерального значения достопримечательное место «Бородинское поле и памятники на нём», характер использования территории которого свидетельствует о изначально принятой концепции объекта, в основе которого лежит ассоци-

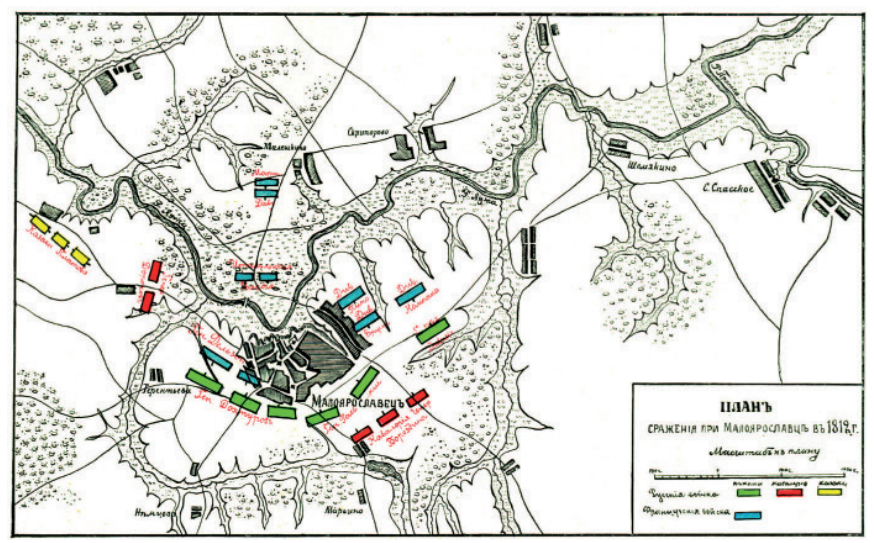

Рис. 4. План сражения при Малоярославце в 1812 году. Взято из книги «Отечественная война и русское общество». Том IV (источник:https://runivers.ru) 
ативный с военными событиями ландшафт и мемориализация полей сражений 1812 года и 1941-1942 годов (рис. 3).

А многим ли известно о знаменательнейшем дне 12 октября 1812 года, когда произошёл бой при Малоярославце. Ведь именно после этого сражения Наполеон вынужден был первый раз отступить и двинуться по Смоленской дороге с целью скорейшего выхода из России. Да, есть в Малоярославце памятник, на котором отчеканена надпись: «Предел нападения, начало бегства и гибели врагов». Так, по мнению военного историка Н.А .Окунева, «самая Бородинская битва не была так нужна для Наполеона, как битва в Малоярославце». Еще сохранились места ландшафта - луговая долина реки Лужи, где стояли наши войска и Наполеоновские, стоит герой Свято-Никольский Черноостровский монастырь, выдержавший все атаки врага, но нет объекта культурного наследия в виде достопримечательного места «Предел нападения, начало гибели врагов России», а жаль, ведь именно С воспитания памяти начинается рост гражданского самосознания (рис. 4.).

Следует отметить, что мест, подобных Малоярославецкому, где решалась судьба государства, на территории Российской Федерации огромное множество, однако вопрос об увековечивании памяти этих военных событий не поднимается ни Министерством культуры РФ, ни региональными ведомствами. Более того, даже инициативно выполненная работа просто замалчивается. Примером может служить проект обоснования границ территории крупного (по занимаемой площади) объекта культурного наследия «достопримечательное место» в районе возрождаемого Спасского Воротынского монастыря на Угре (рис. 5, 6), который выполнялся по просьбе настоятельницы Спасского Воротынского женского монастыря игуменьи Анастасии ${ }^{8}$.

Несмотря на гражданскую цель проекта - сохранение «духа Места» в районе Великого стояния на Угре и мемориального Спасского Воротынского монастыря, воссоздание монастырского комплекса на период его расцвета (XVI - начало XVII века), использование и популяризация исторической среды этого Места как ценнейшего достояния народов Российской Федерации, обладающего сакральной, исторической, культурной и природной ценностью, поднятие духовной культуры социума, восстановление исторической справедливости увековечиванием памяти Великого стояния на Угре и роли Спасского Воротынского монастыря как памятного «Знака» в судьбе становления Российского государства на рубеже XVII века - идея не была поддержана в органах охраны наследия Калужской области. Хладнокровно отнеслись к этому и в Министерстве культуры РФ. А ведь это место колоссальной значимости для нашего государства. Именно здесь, в районе монастыря, в те далёкие годы (1480), практически решалась судьба независимости будущей России, основой которого (государства) стало Московское княжество, добившееся полной независимости от Орды. Эту независимость отстояли наши предки именно на Угорщине, на территории где князем Во- ротынским был воздвигнут Спасский Воротынский монастырь. Именно эта территория, это Место является сакральной территорией, на которой в 1480 году произошло Великое стояние, ознаменовавшее фактическое падение золотоордынского ига на Руси, длившегося более двух веков - с 1237-го по 1480 год.

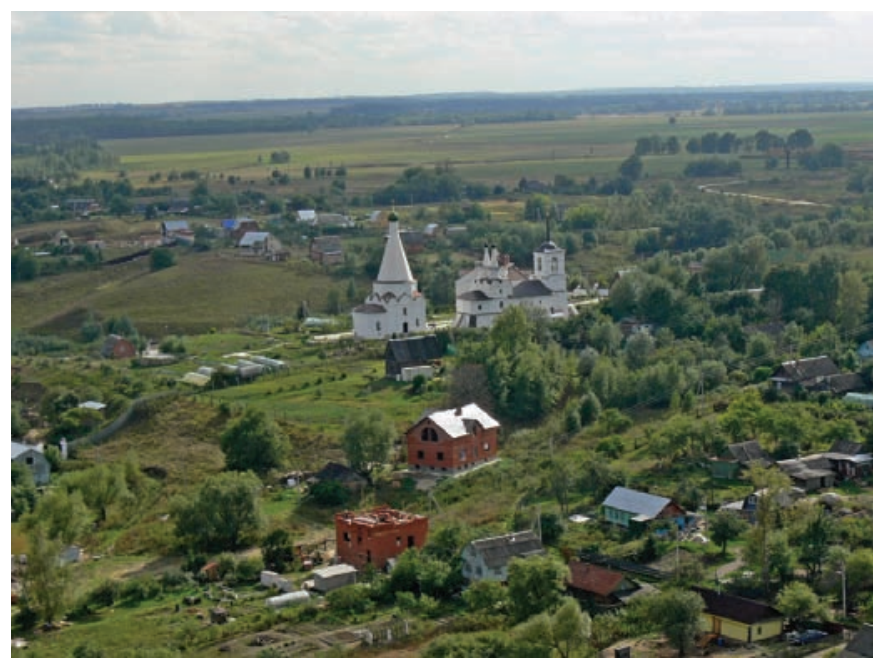

Puc. 5. Панорама Спасо-Воротынского монастыря.

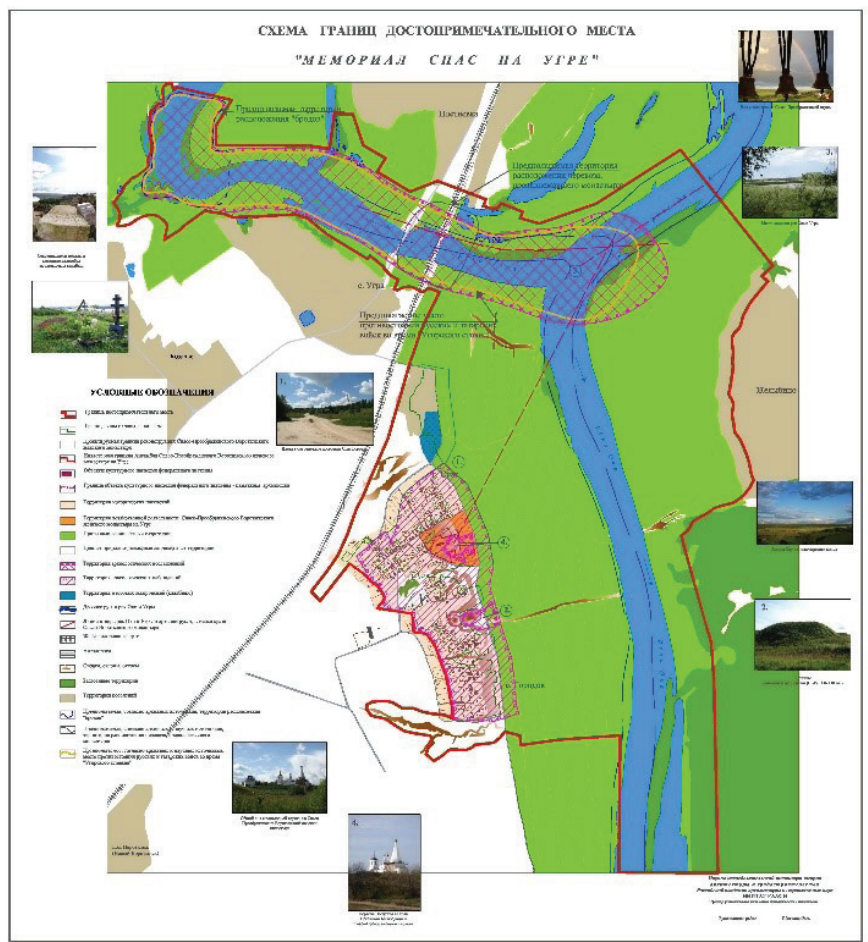

Рис. 6. Схема границ ДМ «Угорщина»

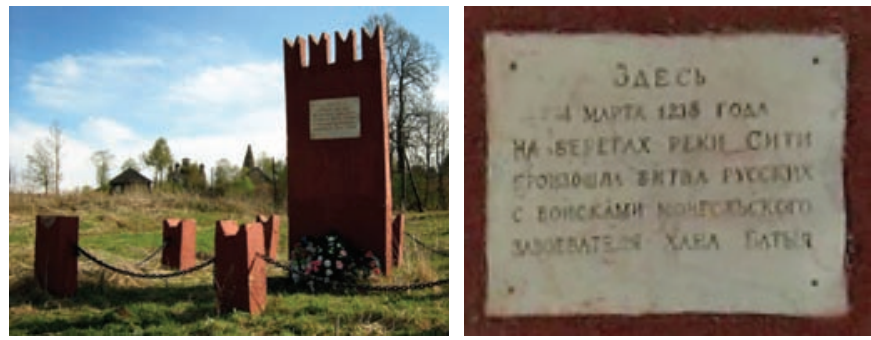

Рис. 7. Обелиск на месте сражения 1238 года на реке Сить 
Не меньшей значимости событие, ознаменовавшее начало тому, что произошло на Угре, - фактическое начало золотоордынского ига, произошло на севере Ярославской области: битва на реке Сити, где русские войска потерпели поражение от войск хана Батыя. Исход этой битвы предопределил трудную историю страны на протяжении более двух столетий. И эта территория не носит соответствующего статуса, а о событии напоминает скромный обелиск (рис. 7),

8 Проект был выполнен в 2008-2009 годы сотрудниками НИИТАГ РААСН. Руководитель проекта - канд. арх., советник РААСН Э.А. Шевченко. Авторский коллектив проекта: Э.А. Шевченко, Е.А. Никитина, Е.Э. Пехтер, при участии канд. арх. Н.В Касьянова. Консультант - настоятельница Спасского Воротынского женского монастыря игуменья Анастасия.

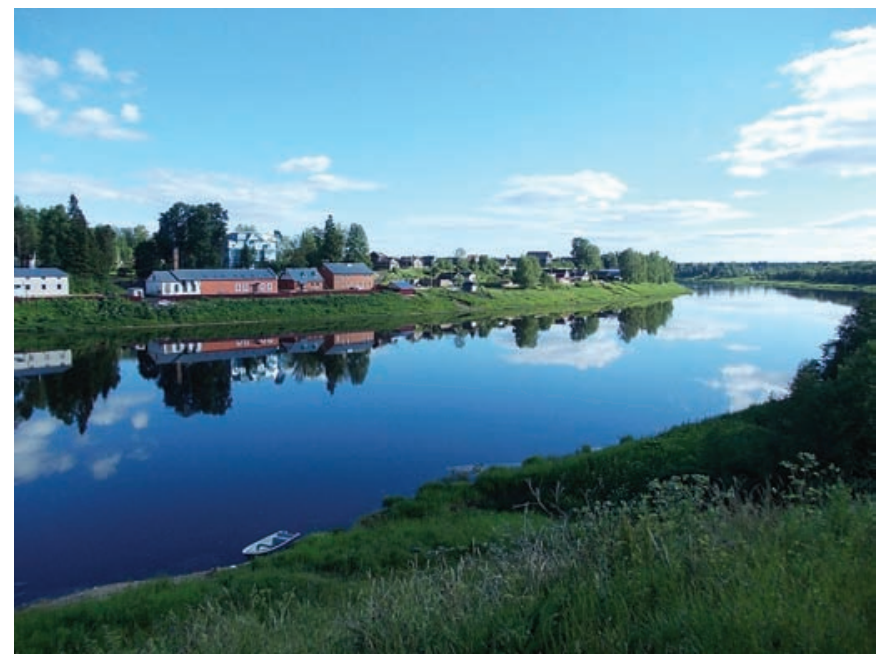

Puс. 8. Деревня Столбово на реке Сясь. Ленинградская область (источник: https://img08.rlo.ru/a6dcb6e70b6027fb4a 4125aa984cefob/c2048x1536/upload.wikimedia.org/wikipedia/ commons/1/14/(ясь.JPG)
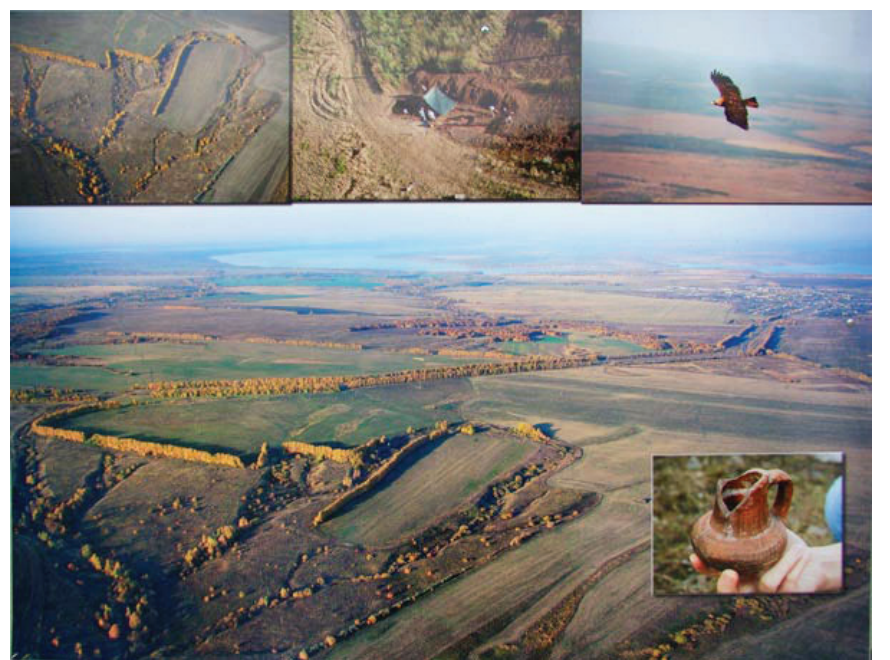

Рис. 9. Объект археологического наследия «Муромский городок» в Самарской области - свидетель развитой городской культуры Волжской Булгарии X-XII веков (источник: http://detym.samddn.ru/images/наша_сам_обл/ istoriy/2_muromskiy_gorodok_15.jpg) хотя вся территория и окрестный пейзаж мало изменились с той далёкой поры - XIII века.

А к какому типу ДМ можно отнести такие места как деревня Столбово, расположенная в Ленинградской области, на реке Сясь в 53 км от современной Новой Ладоги? Здесь, в декабре 1616 года, по инициативе шведской стороны прошли переговоры, а 27 февраля (9 марта) 1617 года был подписан Столбо́вский мир - мирный договор, положивший конец русско-шведской войне 1610-1617 годов. Мирный договор был заключён между Русским царством (царь Михаил Фёдорович) и Шведским королевством (король Густа II Адольф) при посредничестве английского короля Якова I (рис. 8)

Третьей разновидностью ДМ - «памятные места, культурные и природные ландшафты, связанные с историей формирования народов и иных этнических общностей на территории Российской Федерации, историческими (в том числе военными) событиями, жизнью выдающихся исторических личностей», являются ДМ - «памятные места, связанные с жизнью выдающихся исторических личностей».

Установление границ этого типа ДМ, как показала практика, обусловлено конкретным местом пребывания/проживания выдающейся исторической личности. Так, например, ДМ «Есенинская Русь» является самым крупным ДМ этого типа по занимаемой площади, так как исследователи включили в территорию объекта ландшафт вокруг села Константиново, где стоит дом поэта, территории Рыбновского и Рязанского районов, а также часть поселка Солотча. Площадь территории ДМ более 45 тыс. га, в составе десятки сёл и тысячи жителей, оказавшихся «живыми элементами» объекта культурного наследия. Так как в соответствии с № 73-ФЗ ДМ является одним из трёх видов объектов культурного наследия - объектом недвижимого имущества, то можно предположить, что данное ДМ - самый крупный объект недвижимости в России (ДМ как единый объект недвижимости не фигурирует ни в одном кадастре недвижимого имущества, но эта тема тоже не является предметом данной статьи). Однако выдающиеся личности проживали не только за пределами городов, но и в городах, и в этом случае статус ОКН получает квартира или дом, в котором великая личность проживала, но не ДМ. Возникает правомерный вопрос, а чем отличается дом, расположенный в городе, от дома в деревне? В одном случае окружением великого гражданина России является урбанизированная среда, а в другом - природные просторы. Но в обоих случаях именно это окружение влияло на творчество и жизнь личности. В случае расположения места в городе ограничиваемся только фиксацией конкретного объекта недвижимости в качестве ОКН (квартира или дом-усадьба), а в случае расположения места пребывания/проживания в сельской местности начинаются поиски обоснований значительных площадей ОКН в виде ДМ. Согласившись с таким подходом для установления границ ДМ этой разновидности, следует внести в закон поправку, что положение данной части статьи применимо только к загородным местам пребывания великого гражданина России. Если оставить существующее содержание статьи, то возникает вопрос: «почему 
в городах есть только дом-музей или квартира-музей великого гражданина России», но нет территории ДМ, связанной с его прогулками или просто передвижением, при этом следует включить в территорию такого ДМ квартиры или дома друзей, где бывала великая личность, ведь все эти места связаны не только с жизнью этой личности, но и в большей степени, нежели городская квартира, - с его творчеством или подвигом.

Четвертой разновидностью ДМ являются «объекты археологического наследия» (рис. 9).

Этот тип ДМ можно было бы не разбирать, так как законом чётко и однозначно предписано, что «границы территории объекта археологического наследия определяются на основании археологических полевых работ» (№ 73-Ф3 ст. 3.1 п. 3). Да, с этим трудно поспорить, однако существует значительное количество мест, скрытых под землей, которые лишь косвенно, по различным источникам могут быть отнесены к объектам археологии, и отсутствие границы зафиксированной территории такого не визуализированного Объекта приводит к его полной утрате и утрате возможности раскрытия белых пятен в нашей истории. Так, наиболее очевидным примером такой территории может стать территория засечных черт. Границы этой территории будут свидетельствовать о необходимости проведения полевых работ в целях уточнения мест расположения городков, сторожей и других поселений, входивших в состав не просто засечных черт, но сформированных систем расселения. Проведение этих работ способствовало бы подтверждению факта существования линейных градостроительных структур, созданных впервые в мире на территории России. Но для осуществления этой задачи необходимо внести поправку в соответствующую статью закона № 73-Ф3, дополнив позицией - «выявленные на основании различных источников объекты археологического наследия».

Пятой разновидностью ДМ являются «места совершения религиозных обрядов», а седьмой - «религиозно-исторические места». Главным и определяющим для этих разновидностей ДМ является религиозный характер использования мест, следовательно, законодатель, разделив их на два самостоятельных типа, предполагал существенное различие между этими объектами. Однако разница заключает в том, что в одном случае речь идёт о местах, где совершаются только религиозные обряды, а в другом - это некие религиозно-исторические места. Подробно разновидность ДМ «религиозно-исторические места» рассмотрена в Методических рекомендациях 2017 года9 ${ }^{9}$ принятых Минкультом России для апробации: «религиозно-историческое место - это единый комплекс недвижимого имущества, включающий территории и расположенные на них здания и сооружения, а также иные объекты недвижимости, представляющие собой выдающийся целостный историко-культурный и природный комплекс религиозного назначения, имеющий соответствующую конфессиональную принадлежность централизованной религиозной организации... созданный в результате исторического процесса формирования территории, а также совместной деятельности человека и природы, в целях совершения богослужебной деятельности, религиозных та- инств и обрядов, сохранения традиционных форм организации жизни, общественного поведения и традиционные промыслы представителей соответствующих религиозных организаций... проживающих и совершающих религиозные обряды на территории религиозно-исторического места».

Определяющим аргументом при установлении границ этого вида ДМ, в соответствии с методикой, является учёт мнения религиозной организации. Вряд ли можно согласиться с такой формулировкой однозначно. Следует учесть мнение религиозной организации, сопоставив его с данными материалов всех собранных источников, и только тогда рекомендовать фактически верную границу ДМ.

Приведённая формулировка вида ДМ «религиозно-исторические места» фактически раскрывает суть и другой разновидности, а именно ДМ - «места совершения религиозных обрядов».

Обе разновидности ДМ близки по своей сути, так как в обоих случаях в основе фиксации некоей территории, обладающей признаками этих двух разновидностей ДМ, лежит обрядовое действие. Что такое обряд вообще? Это «традиционные действия, сопровождающие жизнедеятельность человека» [3, с. 908] или «совокупность действий стереотипного характера, которой присуще символическое значение» ${ }^{10}$. Для обеих разновидностей характерны значительные площади территорий ими занимаемыми. Таково, например, сакральное место на территории Ярославской области в непосредственной близости от Никитского монастыря в Переславле-Залесском. Это место сегодня именуется «Никитским источником». Предположительно, источник Св. Никиты был сакральным местом дохристианского периода. Во времена христианизации по существовавшей тогда на Руси традиции был переориентирован в православный символ. В настоящее время областной департамент охраны ОКН Ярославской области не настроен включать в единый государственный реестр объектов культурного наследия выявленный ОКН в виде ДМ «Никитский источник» из-за разногласий по границе территории этого объекта. Однако отсутствие нормативного документа или методики обоснования границ такого специфического типа ДМ позволяет разработчикам и экспертам проводить обоснования, исходя из собственных воззрений и знаний, ориентируясь на собственное понимание ценности и значимости этого объекта в истории народов. При этом разработчики вправе рассматривать эту территорию одновременно как «место совершения религиозных обрядов» и как «религиозно-историческое место».

Однако ещё его можно рассматривать как «памятное место, природный ландшафт, связанный с жизнью выдающихся исторических личностей», в данном случае - сжизнью Никиты Переславского. Однако при обосновании границ каждой из перечисленных трёх разновидностей ДМ нельзя использовать в качестве критерия визуальное восприятие объекта - источника. По сути,

\footnotetext{
${ }_{9}^{9}$ Методические рекомендации по отнесению историко-культурных территорий к объектам культурного наследия в виде достопримечательных мест / Минкультуры России; разработчики О.В. Рыжко, Э.А. Шевченко, Д.М. Яцкин [и др.]. - М., 2017.
} 
это подземный водный источник, являющийся объектом природы. Ценность его как места исторической памяти заключается в том, что в XII веке жизнедеятельность Никиты проходила рядом с этим источником: он его обустраивал («ископал»), сюда к нему приходили многочисленные страждущие. То есть конкретный человек и конкретная территория источника, связанная с этой личностью, может быть определена в качестве главного критерия границы локального места водного источника. Можно применить и требования по становлению санитарно защитных зон подземных источников питьевого водозабора. Так, этот источник может быть отнесён к подземному водозабору, тогда граница первого пояса защиты от вредных влияний должна проходить в тридцати метрах от него, а второго пояса - в пятидесяти метрах. Таким образом, для такого типа ДМ можно воспользоваться требованиями САНПиНа и фиксировать территорию такого ДМ, приняв нормативное расстояние от источника равное 30-50 м. Если же главная цель установления границ ДМ - фиксация территории, связанной с жизнедеятельностью исторической личности, то основополагающие критерии определяются исходя из сведений, полученных из исторических источников.

В настоящей статье представлен результат рассмотрения принципа формирования одного из предметов, регулируемых Федеральным законом № 73-Ф3, а именно - порядка «формирования единого государственного реестра объектов культурного наследия (памятников истории и культуры) народов Российской Федерации», одним из основных условий формирования которого (реестра) является установление границ территории объекта культурного наследия. От того, как будет сформирован объект, зависят «особенности владения, пользования и распоряжения объектами культурного наследия... как особым видом недвижимого имущества», но указанная тема не является предметом рассмотрения настоящей статьи.

Результаты экспресс-анализа положений закона о Достопримечательном месте позволили сделать ряд выводов:

1) в целях достижения соответствия требований закона предметам, им регулируемым, необходимо внести поправки в перечень разновидностей ДМ - в частности, изменить формулировку «центр исторического поселения» на «ИСТОРИЧЕСКИЙ ЦЕНТР поселения»; вывести из состава ДМ «памятные места, культурные и природные ландшафты, связанные с историей формирования народов и иных этнических общностей на территории Российской Федерации» и «места захоронений жертв массовых репрессий» (последней разновидности ДМ будет посвящена отдельная статья);

2) дополнить разновидность ДМ самостоятельным подвидом - «культурные ландшафты», дав формулировку в законе.

Не подлежит сомнению, что требуется определённая научно-аналитическая работа по уточнению формулировки, определяющей само понятие «Достопримечательное место» как объект культурного наследия в тексте Федерального закона № 73-Ф3. Следует обратить внимание на выработку более

${ }^{10}$ https://ru.wikipedia.org/wiki/\%D0\%9E\%D0\%B1\%D1\%80\%D1\%8F\%D0\%B4 точного (в сравнении с законодательной формулировкой) определения понятия, данного в упомянутых Методических рекомендациях 2017 года. И, безусловно, необходима ревизия принципов сохранения ОКН вида ДМ, упразднение требования по установлению зон охраны для этого объекта наследия.

Завершить размышления хочется строчками стихотворения Муталипа Беппаева (перевод В. Кострова):

\section{То - камнем замшелым, \\ То - спелой росой, \\ То - стеблем осоки, \\ Что срезан косой, \\ То - яркой звездой, \\ Что горит в вышине,}

Я всматриваюсь в сущее, в естество,

Стараясь постичь и себя самого.

\section{Лuтература}

1. Семёнов Ю.И. Народ. Этнос. Нация / Ю.И. Семёнов // Философия и общество. - 2013. - № 1 (69). - с. 21-35.

2. Каганский, В.Л. Культурный ландшафт и советское обитаемое пространство : сборник статей / В.Л. Каганский. - М. : Новое литературное обозрение, 2001. - 576 с.

3. Культурный ландшафт как объект наследия / Под ред. Ю. А. Веденина, М. Е. Кулешовой. - М. : Российский научно-исследовательский институт культурного и природного наследия имени Д. С. Лихачёва; СПб : Дмитрий Буланин, $2004-620$ c.

4. Советский энциклопедический словарь / Гл. ред. А. М. Прохоров. - М. : Советская энциклопедия, 1985. - 1600 с., ил.

5. Алексеев, Ю.В. Градостроительное планирование достопримечательных мест : Основы планирования. В 2-х т. / Ю.В. Алексеев, Г.Ю. Сомов, Э.А. Шевченко . - М. : АСВ, 2012. - 176 с.

6. Князев, К.Ф. Градостроительные задачи реставрации / К.Ф. Князев // Градостроительные вопросы сохранения и использования памятников архитектуры : Сб. статей СА СССР / Науч. ред. д. арх. В.А. Лавров. - М., 1980 . - 120 с.

7. Охрана ландшафта: Толковый словарь. - М. : Прогресс, 1982. - 272 с.

8. Каганский, В.Л. Переходные зоны как компонент организации культурного ландшафта / В.Л. Каганский // Географические проблемы интенсификации хозяйства в староосвоенных районах : Сб. ст. - М. : ИГАН, 1988. - 146 с.

\section{References}

1. Semyonov YU.I. Narod. Etnos. Naciya [People. Ethnos. Nation]. Filosofiya i obshchestvo [Philosophy and society], 2013, no. 1 (69), pp. 21-35.

2. Kaganskij V.L. Kul'turnyj landshaft i sovetskoe obitaemoe prostranstvo [Cultural landscape and Soviet habitable space] : sbornik statej. Moscow, Novoeliteraturnoe obozrenie, 2001, 576 p.

3. In Vedenina YU. A. (ed), Kuleshovoj M. E. (ed). Kul'turnyj landshaft kak ob"ekt naslediya [Cultural landscape as a heritage 
site]. Moscow, Publ. Institut Naslediya; SPb, Dmitrij Bulanin, 2004, 620 p.

4. In Prohorov A.M. (ed.) Sovetskij enciklopedicheskij slovar' [Soviet Encyclopedic Dictionary]. Moscow, Sovetskaya enciklopediya, 1985, 1600 p., il.

5. Alekseev YU.V., Somov G.YU., SHevchenko E.A. Gradostroitel'noe planirovanie dostoprimechatel'nyh mest: Osnovy planirovaniya V 2-h t. [Urban planning of sights: Basics of planning. In 2 vol.]. Moscow, ASV, 2012, 176 p.

6. K.F. Knyazev. Gradostroitel'nye zadachi restavracii [Urban Restoration Tasks]. In Lavrov V.A . (ed.) Gradostroitel'nye voprosy sohraneniya $i$ ispol'zovaniya pamyatnikov arhitektury
[Town planning issues of conservation and use of architectural monuments]: Sb. statej SA SSSR. Moscow, 1980, 120 p.

7. Ohrana landshafta : Tolkovyj slovar' [Landscape Protection: Explanatory Dictionary]. Moscow, Progress, 1982, $272 \mathrm{p}$.

8. Kaganskij V.L. Perehodnye zony kak komponent organizacii kul'turnogo landshafta [Transition zones as a component of cultural landscape organization]. Geograficheskie problemy intensifikacii hozyajstva $v$ staroosvoennyh rajonah [Geographic problems of intensification of the economy in the old-developed areas] : Sb. st. Moscow, IGAN, 1988, 146 p.

Шевченко Элеонора Арсеновна (Москва). Кандидат архитектуры, советник РААСН. Доцент кафедры «Градостроительство» ФГБОУ В0 «Национальный исследовательский Московский государственный строительный университет» (129337, г. Москва, Ярославское шоссе, д. 26. НИУ МГСУ). Эл.почта: shegal1948@mail.ru.

Лукашев Андрей Владиславович (Ярославль). Президент НКО «Фонд “Институт проблем устойчивого развития городов и территорий"» (150000, Ярославль, ул. Чайковского, д. 56-1. НК0 «Фонд «ИПУРГ»). Эл.почта: avlukashev@yandex.ru.

Shevchenko Eleonora Arsenovna (Moscow). Candidate of Architecture, Adviser of RAACS. Associate Professor of the Urban Planning Department at the National Research Moscow State University of Civil Engineering (26 Yaroslavskoye Highway, Moscow, 129337. NIU MGSU).E-mail: shegal1948@mail.ru.

Lukashev Andrej Vladislavovich (Yaroslavl). Prezident of Foundation "Institute of problems of sustainable development of towns and territories"» (150000, Yaroslavl, Chaikovski st., 56-1. NK0 «Fond “IPURG”»). E-mail: avlukashev@yandex.ru. 